\title{
SEEKING JUSTICE, GUARANTEEING PROTECTION AND ENSURING DUE PROCESS: ADDRESSING THE TENSIONS BETWEEN EXCLUSION FROM REFUGEE PROTECTION AND THE PRINCIPLE OF UNIVERSAL JURISDICTION*
}

\author{
JEFF HANDMAKER **
}

\begin{abstract}
Efforts to secure protection for refugees in the Netherlands are being undermined by over-enthusiastic use of the exclusion principle in refugee status determination procedures. Inappropriate use of the exclusion principle is tied to accelerated (albeit ineffective) efforts to secure justice for human rights violators. As this article argues, the tensions that arise are unacceptable, but can be appropriately addressed through a (re)commitment to both principles and pragmatism. A principled commitment would ensure that due process is thoroughly respected in asylum determination procedures. This must be accompanied by a pragmatic, rights-based application of the aut dedere aut judicare principle (extradite or prosecute), reinforced by strengthened coordination between the government agencies responsible for asylum and prosecution.
\end{abstract}

\section{INTRODUCTION}

Much has been written about the current challenges facing the international asylum regime, with some even claiming that there is a 'crisis' ${ }^{1}$ in the regime

\footnotetext{
* Originally presented at the Symposium, 'Universal Jurisdiction: Diversity and Inclusivity', organised by Africa Legal Aid (www.afla.unimaas.nl), Maastricht, the Netherlands, 7 december 2001. I am especially grateful to Helen Moffett on matters of syntax, idioms and other such grammatical nightmares. Thanks also go to Evelyn Ankumah, Executive Director of Africa Legal Aid, for inviting me to speak at the Symposium, Dr. Edward Kwakwa and Jann Kleffner, both of whom kindly provided extensive feedback on earlier versions of this article and to Marion Soffers and Mariette Timmer of Weteringkade Advocaten in The Hague, the Netherlands, with whom I collaborated on the 2001 written submission (supra note 28).

** LLB (Newcastle), LLM (SOAS, London), Freelance Consultant, Rea Hamba Advice, the Netherlands - www.reahamba.nl, and a Ph.D. candidate at Utrecht University, Faculty of Law.

1 Hathaway, J., 'The Emerging Politics of Non-Entrée', Refugees, Issue 91, pp. 40-41 and Hathaway, J. (ed.), Reconceiving International Refugee Law, Martinus Nijhoff, The Hague, 1997. This is contested by some, who hold that arguing (in support of or against) the 'death of asylum' could validate the current objections of States, and ultimately become a 'self-fulfilling prophecy'. These views were expressed at the Asylum and the Politics of Refuge conference at Southampton University, 29 June 1998. See also Verdirame, G., 'Death of Asylum': Fallacies and Dangers, $6^{\text {th }}$ IRAP Conference, Jerusalem, 13-16 December 1998.
}

Netherlands Quarterly of Human Rights, Vol. 21/4, 677-695, 2003.

@ Netherlands Institute of Human Rights (SIM), Printed in the Netherlands. 
due to changed priorities in global politics and an increase in the mobility of persons seeking asylum. Whether or not a 'crisis' exists, there has undoubtedly been a tendency in recent years by States that have traditionally offered refugee protection to restrict the numbers of those being granted asylum.

This restrictive tendency in the asylum regime has been paralleled by the rapid development of international criminal law. Discussions on criminal law and refugee protection have largely been carried out in isolation of each other, and there is still considerable lack of clarity on the connection between these two legal principles. ${ }^{2}$ These trends have had the unfortunate consequence of splitting the human rights discourse, thus raising considerable tensions between two separate legal traditions that should be operating in tandem with each other. It has also created a significant risk that fundamental human rights may be violated in the attempt to seek 'justice'.

Tragic events in the United States on 11 september 2001, followed by an aggressive military response by (predominantly) the USA and its allies, have accelerated restrictive approaches towards foreigners and asylum applications in particular. At the same time, there has been great resistance to the pursuance of justice at a supra-national level. The United States, which continues to openly resist the establishment of an International Criminal Court, has proposed that military commissions try persons suspected of terrorism, in spite of claims by some that this would be illegal, both in terms of its own constitution and international law. ${ }^{3}$ The USA has also extended its policy of routine detention of asylum seekers and adopted an increasingly restrictive approach towards the interpretation of asylum claims and treatment of asylum seekers. ${ }^{4}$ Other countries have emulated similarly restrictive approaches, ${ }^{5}$ including members of the European Union. According to a (leaked) memorandum, the EU is reportedly engaged in extensive talks with the United States to 'harmonise' more stringent checks on migrants, although the EU alleges that some proposed measures could

2 One commentator compares the reluctance of the Dutch Government to deliberately address the issue to the habits of an ostrich 'sticking its head in the sand'; see Ferdinandusse, W.N., 'De struisvogel in ons', Nederlands Juristenblad, Vol. 40, 8 November 2002, pp. 1985 - 1987.

Fitzpatrick, J., 'The Constitutional and International Invalidity of Military Commissions under the november 13, 2001, "Military Order", unpublished, posted on IMMPROF list-server 14 November 2001.

4 In 2001, the United States created the 'Department of Homeland Security', which brought together a range of government agencies, under the auspices of the Immigration and Naturalisation Service (INS). Measures that have been introduced include compulsory detention, irrespective of their means of entry, of asylum seekers coming from a (confidential) list of 'designated countries'. The DHS/INS is also seeking to overturn a (relatively liberal) provision concerning gender-related persecution. See 'Assessing the New Normal: Liberty and Security for the Post-September 11 United States', Lawyers Committee for Human Rights, New York, 2003.

5 Human Rights Watch World Report 2002 (events of 2001), Human Rights Watch, New York, www.hrw.org. 
contravene data protection laws. ${ }^{6}$ The treatment of refugees as potential security risks is of particular concern to the office of the United Nations High Commissioner for Refugees (UNHCR), which has urged States 'to strike a careful balance between additional security needs and existing international refugee protection principles'. ${ }^{7}$ Human rights advocates and academics have also raised concerns that the enthusiastic participation of governments in the 'war against terrorism' has increased the threat of violation of the non-refoulement principle, ${ }^{8}$ which is an irrevocable principle considered to be part of international customary law. ${ }^{9}$

Such events make it all the more important for States and other roleplayers to be reminded of their international obligations towards refugees and international justice, and to remain reflective in their approaches to difficult questions surrounding both issues. In order to ensure that protection exists for those who may need it, and that justice is pursued against those who may deserve it, it is prudent to step back and examine the emerging tensions between these two important objectives, while at the same time considering what scope there might be to resolve them.

In my arguments in this article, I do not deny the need to bring human rights violators to justice, indeed quite the contrary. However, I will seek to question at what cost this is currently being undertaken in the Netherlands. In my view, fundamental principles underlying refugee protection and human rights are being eroded in a hasty and ill-unconsidered manner by the apparent, though ineffective, pursuit of 'justice' in the Netherlands (and indeed elsewhere in the world), without due regard to the far-reaching consequences of such hasty actions.

\section{PUTTING THE ISSUE IN CONTEXT}

Refugee law and international criminal law (including the principle of universal jurisdiction) operate with sometimes overlapping functions that ought to be complementary, but which have existed in an uneasy relationship in practice. This has much to do with the fact that exclusion applies to a much broader category of offences, and requires a lower

6 'Row between European Union and United States over Passenger Checks', Telepolis, 23 January 2002. This refers to a document released by NGO Eurowatch, dated 12 November 2001 and to be found at www.heise.de (last checked on 22 February 2002).

7 'Care urged in balancing security and refugee protection needs', Press Release, UNHCR, 3 October 2001.

8 The 'negative' principle in international refugee law (which may well be considered a peremptory norm in international law) provides that no one may be sent back to a country where they would face a well-founded fear of persecution. See Goodwin-Gill, G., The Refugee in International Law, Clarendon Press, Oxford, $2^{\text {nd }}$ ed., 1996, p. 11

$9 \quad$ Bruin, R. and Wouter, K., 'Terrorisme en refoulement: De invloed van de strijd tegen het terrorisme op het absolute karakter van de refoulementverboden', Nieuwsbrief Asiel en Vluchtelingenrecht, Vol. 7, 2002, pp. 428-438. 
evidentiary threshold, ${ }^{10}$ than provided for in international criminal law and in terms of the universal jurisdiction principle.

\subsection{Refugee Law Aims Primarily to Protect Victims}

The notion of 'refugeehood' and the granting of political asylum are longstanding legal principles. Throughout juridical history, these concepts have been enshrined here and there in various documents, but they only really rose to prominence in the last half-century. In particular, the horrors of the Second World War, and particularly the Holocaust, which were accompanied by massive displacement of people, created an urgent impetus to extend the reach of humanitarian law (protecting combatants and, especially, civilians during times of war) and to establish specific legal rules to protect those forcibly displaced.

Beyond humanitarian law, refugee law is also firmly based on human rights principles. Following in the footsteps of the 1948 Universal Declaration of Human Rights ${ }^{11}$ and the creation of the United Nations itself in 1945, the 1951 United Nations Convention Relating to the Status of Refugees, ${ }^{12}$ accompanied by the 1950 Statute of the Office of the United Nations High Commissioner for Refugees, ${ }^{13}$ was one of the first major projects of the UN. However, the UNHCR agency originally possessed only a limited mandate, and was created in response to European concerns to ensure the protection of Europeans. It was in fact only intended to be a temporary agency.

With the expansion of the notion of human rights (and the continuing violation of these rights), the liberation of formerly colonised States and an increasingly globalised responsibility to respond to unsettling events in all parts of the world, the concept of refugeehood gradually developed and was extended. Following a Protocol to the 1951 Convention, ${ }^{14}$ the development of international human rights law and various regional refugee instruments, ${ }^{15}$ refugee law now (in theory) extends protection to broad categories of persons who suffer persecution.

Refugee law, through the 1951 Refugee Convention, includes two interrelated functions, namely a protection function (Article 1A) and an exclusion function (Article 1F). In the context of this essay, we can see

\footnotetext{
$10 \quad$ As acknowledged by Ferdinandusse, loc.cit. (note 2), at p. 1985.

11 UN General Assembly Resolution 217 A(III) of 10 December 1948.

12 Entry into force: 22 April 1954, 189 UNTS 150.

13 UN General Assembly Resolution 428(V) of 14 December 1950. The Statute of the UNHCR's immediate predecessor was the 1946 Constitution of the International Refugee Organization, entered into force on 20 August 1948, 18 UNTS 3.

14 Protocol Relating to the Status of Refugees, entry into force: 4 October 1967, 606 UNTS 267.

15 These include the 1950 European Convention on Human Rights and Fundamental Freedoms, entry into force: 3 September 1953, ETS, No. 5; and the 1969 Convention on the Specific Aspects of Refugee Problems in Africa, Organization of African Unity, entry into force: 20 June 1974, 1000 UNTS 46.
} 
these as protecting the 'deserving refugee' and ensuring 'that serious international criminals do not escape punishment' ${ }^{16}$ This said, there is no requirement in refugee law to ensure that excluded persons are prosecuted or even 'rendered' to the authorities. ${ }^{17}$

The legal standard of proof for invoking Article 1F of the 1951 Convention is 'serious reasons', a notoriously vague legal concept that has been the subject of considerable debate ${ }^{18}$ (and about which more will be said later). The scope of exclusion covers three categories of offences: international crimes ${ }^{19}$ - Article $1 \mathrm{~F}(\mathrm{a})$; serious non-political crimes Article $1 \mathrm{~F}(\mathrm{~b})$; and acts contrary to the principles of the United Nations Article $1 \mathrm{~F}(\mathrm{c}) .^{20}$ In most cases, it is only the first category of exclusion Article $1 \mathrm{~F}(\mathrm{a})$ - that is likely to overlap with international criminal law and the universal jurisdiction principle, although some have controversially (and in the author's view mistakenly) argued that category $1 \mathrm{~F}(\mathrm{~b})$ of exclusion applies to other offences as well, such as terrorism and hijacking. ${ }^{21}$

\subsection{Criminal Law / Universal Jurisdiction Both Aim Primarily to Seek Justice}

International criminal law as a unique juridical concept also emerged roughly during the last half-century, through the development of humanitarian law and human rights principles that aimed to challenge

16 Gilbert, G., 'Current Issues in the Application of the Exclusion Clauses', UNHCR, Geneva, 2001, p. 3. Commissioned by UNHCR as a background paper for an expert roundtable discussion on exclusion organised as part of the Global Consultations on International Protection.

17 Fitzpatrick, J., 'The Post Exclusion Phase', International Journal of Refugee Law, Vol. 12, Special Supplementary Issue, 2000, p. 274.

18 Fitzpatrick (ibidem, at p. 276) notes that 'its meaning has never been conclusively defined (...) resulting in inconsistent interpretation by national status authorities'. Guglielmo Verdirame holds that the standard is 'high, and, at least, higher than the balance of probabilities standard, which normally applies to civil cases', in: 'The Application of the Exclusion Clauses in International Refugee Law and their Relationship with Universal Jurisdiction', AFLA Quarterly, July - September 2001, Africa Legal Aid, Maastricht.

19 Includes 'crimes against peace, a war crime, or a crime against humanity, as defined in the international instruments (...) in respect of such crimes' - Art. 1F(a), 1951 UN Convention, supra note 14.

20 For more on this, see Edward Kwakwa, 'Article $1 \mathrm{~F}(\mathrm{c})$ : Acts Contrary to the Purposes and Principles of the United Nations', International Journal of Refugee Law, Vol. 12, Special Supplementary Issue, 2000, p. 79.

21 Peter van Krieken, in: Krieken, P.J. van, (ed.), Refugee Law in Context: The Exclusion Clause, T.M.C. Asser, The Hague, 1999, at pp. 5-6. However, commentators such as Verdirame, loc.cit. (note 18) and Bruin and Wouter, loc.cit. (note 9), resist this expansionist tendency. Verdirame argues that as 'there is still no satisfactory international legal definition of terrorism, the inclusion or exclusion of members of liberation and resistance movements could become a function of the relationships of friendliness or enmity that might exist between the host state and various political movements'. Ibidem, at p. 34 . 
impunity by prosecuting those responsible for perpetrating human rights violations.

The relative success of various ad hoc tribunals set up in response to massive human rights violations that took place in the former Yugoslavia, Republic of Rwanda and (recently) Sierra Leone, have accelerated the development of a Statute to create an International Criminal Court (ICC). Further, the success of these tribunals has also stimulated an increasing willingness on the part of States to prosecute human rights violators in their own countries' courts using the concept of universal jurisdiction, essentially an instrument of international criminal law that allows States to exercise national jurisdiction over individuals in respect of certain international crimes that are deemed to be of concern to all humanity, without regard to the nationality of the accused, the victim, or the location where the alleged crime took place.

Universal jurisdiction draws essentially from two sources: international humanitarian law and more recent development in international human rights law and case law jurisprudence. The primary function of international humanitarian law is to limit levels of violence in armed conflicts by regulating the methods and means of conducting war, violations of which are commonly referred to as 'war crimes', and are further defined in the 1949 Geneva Conventions and 1977 Protocols. ${ }^{22}$ Its secondary function is to regulate the treatment of combatants and non-combatants - by extension, this protection function also operates as a tool to protect those forcibly displaced.

The universal jurisdiction principle also draws a range of other International Conventions, including the Convention Against Torture ${ }^{23}$ and jurisprudence arising out of the various ad hoc tribunals created in the last century. ${ }^{24}$

As commentators such as Kamminga have observed, ${ }^{25}$ while universal jurisdiction draws from a range of juridical sources, it is important to stress that it is essentially a concept that refers to the jurisdiction of national courts, and should be distinguished from the express jurisdiction exercised by supra-national authorities in terms of binding treaties, such as the ad hoc tribunals or the ICC.

\footnotetext{
22 See www.icrc.org/ihl.

231984 Convention against Torture and Other Cruel, Inhumane or Degrading Treatment or Punishment, UNGA Resolution 39/46 of 10 December 1984 (entry into force June 1987).

24 These include the Nuremberg and Tokyo War Crimes Tribunals, established in the aftermath of the Second World War, the Rwanda Tribunal established in Arusha, Tanzania to adjudicate crimes committed during the Rwandan genocide of 1994, the International Criminal Tribunal for the Former Yugoslavia established in The Hague, and the recently established Sierra Leone Tribunal.

25 See Kamminga, M., 'Lessons Learned from the Exercise of Universal Jurisdiction for International Crimes', African Legal Aid Quarterly, Africa Legal Aid, Maastricht, July September 2001.
} 
The ability to seek justice, whether in a national jurisdiction or international tribunal, is bound to remain true to the foundation (and established principles) of human rights, upon which criminal law is based.

\subsection{Interfacing of International Criminal Law and Exclusion}

Given their overlapping histories, it is no surprise that in recent years, developments in both refugee law and international criminal law have led to the interfacing of these two legal regimes; nevertheless, how this should operate has not always been carefully thought through.

As mentioned earlier, one of the main causes of concern is that the standards for establishing whether one is excluded or criminally liable are very different. On the other hand, there is clearly some commonality in the range of offences that can invoke the exercise of both exclusion and universal jurisdiction (often concurrently): crimes against humanity; war crimes; crimes against peace and possibly other serious crimes.

\section{WHERE DO THESE TENSIONS ARISE? THE OPERATION OF EXCLUSION AND UNIVERSAL JURISDICTION IN THE NETHERLANDS ${ }^{26}$}

As a consequence, tensions between the exercise of exclusion and universal jurisdiction have emerged. These tensions take a variety of forms: for example, exclusion cannot be reserved for the most serious war criminals, ${ }^{27}$ nor is it practicable for criminal justice systems to exercise the universal jurisdiction principle in respect of everyone found to be excluded. Elements of these tensions can be seen in the operation of exclusion and universal jurisdiction in the Netherlands.

The Netherlands is a useful example in that it still is considered to have a relatively liberal refugee status determination system, which processes one of the largest annual asylum caseloads in Europe. ${ }^{28}$ It is also one of the few countries to have tested the principle of universal jurisdiction in the case of

26 This section draws heavily on a more extensive report that examined various policy documents of the Dutch Government, practices of the Dutch immigration service (IND) and contemporary academic opinion on the legal standards for the operation of exclusion in international law. See Timmer, M., Soffers, M. and Handmaker, J., 'Perspectives on the legal basis and practice of the Netherlands government regarding exclusion of refugee status in terms of Article1F of the 1951 United Nations Convention Relating to the Status of Refugees', Written Submission to the UNHCR Global Consultations on Refugee Protection, Exclusion of Refugee Status, 3-4 May 2001, at www.reahamba.nl/documents/global.htm.

27 Verdirame, loc.cit. (note 18).

28 However, see 'Fleeting refuge: The triumph of efficiency over protection in Dutch asylum policy', Human Rights Watch, April 2003, New York. 
Bouterse $^{29}$ although no prosecution subsequently took place. Furthermore, the Netherlands is host to the ICC, and Dutch Parliament has passed legislation to bring its law into conformity with the Court's Statute. ${ }^{30}$

While the proportion of excluded asylum cases has traditionally been quite small in the Netherlands, in recent years the numbers have increased dramatically, ${ }^{31}$ through an increasing willingness to invoke the so-called 'exclusion clause' under Article $1 \mathrm{~F}$ of the UN Refugee Convention. In a letter dated 28 November 1997 addressed to the second chamber of the Dutch Parliament, ${ }^{32}$ the State Secretary of the Ministry of Justice responsible for Immigration comprehensively explained the Dutch Government's policy on Article 1F, which, as illustrated below, represented a dramatic break from previous practice.

A report by the author and two practising lawyers in the Netherlands ${ }^{33}$ that examined this policy and its implementation three and a half years later concluded that the process of asylum (and exclusion) determination contained inadequate safeguards to protect the legitimate rights of asylum applicants. In short, the procedure in the Netherlands for deciding whether an applicant ought to be excluded from refugee protection falls far short of basic principles of due process and natural justice, both in the policy itself and in its implementation.

Consequently, in the context of Article 1F's inter-relationship with international criminal law, major concerns arise, since the implications of certain exclusion determinations mean that rejected asylum applicants either become subject to deportation to their country of origin or another jurisdiction, or, in appropriate cases, arrest, indictment and prosecution under the universal jurisdiction principle. This follows from the principle of aut dedere aut judicare, which provides that one who is suspected of having committed international crimes ought either to be tried in the jurisdiction in which he or she is found, or deported to another jurisdiction willing to try the suspect.

\subsection{Interview or Interrogation?}

During the initial stage of the asylum procedure in the Netherlands, two interviews take place. The first hearing, according to the department's own rules, is intended only to determine nationality, confirm identity and

\footnotetext{
29 The Netherlands vs Bouterse, decided in the Amsterdam Court of Appeal, 20 November 2000.

$30 \quad$ The Dutch Parliament passed the ICC Implementation Act on 20 June 2002.

31 The Dutch Government began keeping records of exclusion cases in 1989. In August 2000, the total number reached 109. Six months later, at the end of January 2001, the number had reached 170. This is according to Weteringkade Advocaten. No official figures could be obtained from the Dutch Government to confirm this. 
establish travel route (although lawyers have noted that other questions are also asked). This is followed by a more detailed second interview. ${ }^{34}$ Depending on an Immigration and Naturalisation Service (IND) official's interpretation of the results of the first interview and IND policy papers referring to certain countries and groups, ${ }^{35}$ this interview will take one of two courses:

1) a 'normal' Article 1A inclusion enquiry to determine the applicant's motivations in applying for asylum, conducted by an ordinary immigration officer; or

2) a 'special' Article 1F exclusion enquiry, conducted by an official specially trained in exclusion issues.

Clearly, questions asked at the first interview can have potentially serious consequences for applicants if they become subject to a 'special' Article $1 \mathrm{~F}$ enquiry, as this is heavily biased towards determining whether the subjects ought to be excluded rather than whether they are in need of protection. Clients have reported that these Article $1 \mathrm{~F}$ investigations closely resemble police interrogations. ${ }^{36}$

\subsection{Abandoning Inclusion Before Exclusion}

It is fundamental to the integrity of any national asylum/refugee regime that access to an asylum procedure is guaranteed. Determining first whether or not an asylum applicant deserves international protection, before considering whether such a person might be excluded from this protection is, in this context, inextricably linked to the fundamental principle of presumption of innocence. ${ }^{37}$

The Dutch Government's earlier position on this matter was that a 'twopart investigation' be carried out involving both Article $1 \mathrm{~A}$ and $1 \mathrm{~F}$ determinations:

(1) under Section 1A: an investigation into whether the person concerned was prevented from calling upon the authorities of his own

34 This is the so-called 'nader gehoor', which is the most important basis upon which a determination to grant status and/or to exclude is made.

35 This is evidenced by various answers to questions put to the Minister of Justice and/or the Minister of Foreign Affairs in the Dutch Parliament (Tweede Kamer) concerning, for example, extremists (Nr. 1718, Vergaderjaar 1997-1998, Aanhangsel 3531) and communists from Afghanistan (Nr. 534, Vergaderjaar 1994-1995, Aanhangsel 1089), as well as policy papers put forward to Parliament by the Minister of Justice, for example, concerning Turkish and Kurdish asylum seekers (Vergaderjaar 1999-2000, 19 637, nr. 494).

36 Report, loc.cit. (note 26), p. 4.

37 Striving for administrative efficiency should not unacceptably compromise the rights of asylum applicants. See Gilbert, loc.cit. (note 16). 
country to protect him from certain risk of persecution on account of to [sic] race, religion, nationality, membership of a social group or political conviction and (2) under Section 1F: an investigation into whether there were serious reasons for considering that the person concerned could be denied refugee status on the grounds of this section. ${ }^{38}$

However, in the 28 November 1997 letter to parliament referred to above, the State Secretary made reference to Article 14(2) of the Universal Declaration of Human Rights and the Travaux Préparatoires to the 1951 Geneva Convention, arguing that the government's policy was consistent with the country's treaty obligations, yet taking the position that neither the Convention nor the Dutch Immigration Act applied in circumstances where an asylum seeker (applicant) might be excluded under section 1F.

This new stance confirmed the position reflected in an earlier statement addressed to the Speaker of the Dutch Parliament on 19 November 1997, which held that in considering $1 \mathrm{~F}$, 'there is nothing in the text of the Convention to indicate that Article 1A must be applied first'. This represented a major reversal in policy, apparently on the grounds of 'highly laborious enquiries' ${ }^{39}$

Insistence that an Article 1A enquiry need not be conducted prior to an Article $1 \mathrm{~F}$ enquiry has been a position firmly maintained by the government, in spite of at least two appeals by the UNHCR to the Dutch Secretary of State for Immigration on the grounds that such a position was not justifiable. ${ }^{40} \mathrm{~A}$ Dutch court in Haarlem regretfully decided to support the government's position in a decision dated 27 April 1999. ${ }^{41}$

Such a position is contrary to the spirit and purpose of the 1951 Geneva Convention. ${ }^{42}$ As Gilbert has stated, exclusionary factors in any case tend to come to light during the course of the determination process in terms of Article $1 \mathrm{~A}(2)$ of the Geneva Convention. ${ }^{43}$ It is therefore difficult to understand why Article $1 \mathrm{~A}$ and Article $1 \mathrm{~F}$ enquiries cannot be incorporated into a single procedure.

\footnotetext{
38 Policy Memo (English translation) by the State Secretary for Justice (Immigration), addressed to the Speaker of the Lower House, Re: Article 1F of the 1951 Geneva Convention, 19 November 1997.

$39 \quad$ Policy Memo, loc.cit. (note 38).

40 Cited in a case before the Dutch court in Haarlem, upheld by the Rechtbank Den Haag, Haarlem, 27 April 1999, AWB 98/3609.

41 Haarlem court case, idem.

42 Note the comment by Gilbert that the 'increased interest in exclusion is part of a wider policy to limit refugee status in general', loc.cit. (note 16), p. 5.

43 Ibidem, p. 29, referring to the UNHCR Handbook on Asylum Determination.
} 


\subsection{Wrongfully Shifting the Burden of Proof}

According to the Dutch Government's policy, an applicant must have had 'personal and knowing' involvement in offences contemplated by Article $1 \mathrm{~F}$, consistent with the so-called 'Canadian Standard', where there is an 'indication' that the applicant's story contains the following elements:

1) Whether the applicant participated in (or provided services to) an organisation that allegedly committed crimes contemplated in Article $1 \mathrm{~F}$;

2) Whether the applicant was an active and conscious member, or working for the organisation (and, if so, in what capacity); and

3) Whether it was possible that after discovering that the organisation was involved in such crimes, the applicant distanced him/herself from the organisation.

According to Article 1F, the burden of proving involvement in such offences ought to lie with the government. ${ }^{44}$ However, in practice, with some applicants, the IND effectively makes a pre-determination of whether an organisation (and by association the applicant) has a 'cruel purpose', without publishing information disclosing the basis for making these determinations. ${ }^{45}$ This has the negative effect of shifting the burden of establishing non-involvement in offences contemplated by Article $1 \mathrm{~F}$ to the applicant.

\subsection{Lack of Access to Competent Legal Advice}

Access to competent legal advice at the early stages of the procedure is virtually non-existent for most applicants. This is crucial for applicants subject to Article 1F enquiries on the basis of information gathered in the first interview, as the conflicting goals of identifying potential violators of international crimes and protecting persons from persecution under refugee law make such enquiries complicated and potentially incriminating.

44 Some, including a senior policy advisor to the State Secretary for Immigration in the Netherlands, erroneously question this. Special Advisor on International Affairs of the Dutch Ministry of Justice, Peter van Krieken, wrote that 'the burden of proof is obvious: the executive needs to indicate that it has serious reasons for exclusion' ('Germany and Article 1F: the urgent need to implement a basic principle', AWR Bulletin, Vol. 38, No. 3-4, 2000, pp. 188-196, at p. 193). He goes on to claim that 'the applicant has to prove his case (that he/ she does not fit the description) with due reference to the benefit-of-the-doubt principle'.

45 See, for example, a decision in the Rechtbank 's-Gravenhage, 9 November 1999, AWB 99/671 VRWET. Thus, it seems that the Canadian test is not being applied generally, but only in circumstances where an applicant is not believed to be a member of an organisation with a 'cruel purpose'. 


\subsection{Illusion of Confidentiality}

Before the detailed interview takes place (whether this is the 'normal' Article 1A or 'special' Article 1F interview), applicants are told by IND officials that they must not hold back any relevant information, and that this information will be treated in confidence. They are not informed of the consequences of a possible Article1F determination. ${ }^{46}$

However, the promise of confidentiality is an illusion, as all information collected during the interview process is handed over to the public prosecutor in the event that an applicant is, in fact, found to be excluded in terms of Article 1F.

\subsection{Inappropriate Reliance on Country Reports}

Information provided by the Ministry of Foreign Affairs in the form of country reports (ambtsbericht) results in applicants from certain countries being more likely to be subject to an Article1F investigation than others. Reliance on these country reports thus plays a significant role in predetermining whether applicants ought to be subject to the exclusion process. As explained in the original report, ${ }^{47}$ these country reports are often unreliable and difficult to challenge, as the sources of information are often missing; yet, in spite of this, the IND regards the information they provide about groups or people as conclusive.

\subsection{Inability to Prosecute}

Finally, the Dutch Government has clearly indicated its commitment to ensure that alleged perpetrators of human rights violations do not escape with impunity. ${ }^{48}$ But while the Government has shown itself to be enthusiastic in invoking the Article 1F exclusion clause, it has not delivered on its commitment to bring accused persons to justice. ${ }^{49}$

\footnotetext{
46 It is widely observed by practitioners and refugee advocates that asylum applicants often make their case worse by trying to say what they imagine the interviewer is expecting to hear.

47 Report, loc.cit. (note 26), p. 4.

48 Policy Memo, loc.cit. (note 38): 'The Netherlands is obliged by these Conventions to see to the punishment or extradition of any persons accused of such offences on an aut dedere aut judicare basis'.

49 Among a number of wide-ranging observations, the extensive evaluation of the 'National Investigations Team for War Criminals' by Beijer, Klip, Oomen and Van der Spek found that 'within the period under evaluation, not one writ of summons was issued', Samenvatting evaluatie NOVO (EWB-rapport) on the website of www.ministerievanjustitie.nl, p. 1. Full reference to the report is Beijer, A., Klip, A.H., Oomen, M.A., Van der Spek, A.M.J., Evaluatie van het Nationaal Opsporingsteam voor Oorlogsmisdrijven, Willem Pompe Instituut voor Strafrechtswetenschappen, Universiteit Utrecht, Utrecht, 2002.
} 
The current practice in the Netherlands is that decisions in terms of Article $1 \mathrm{~F}$ are handed over to the office of the public prosecutor in Arnhem, which is responsible for the prosecution of persons suspected of having committed war crimes. A special 'Novo Team' of 15 persons $^{50}$ was established and tasked with tracing and prosecuting persons suspected of committing war crimes, particularly those from Afghanistan and the former Yugoslavia. In the period January 1998 - January 2001, 170 cases were sent on to the public prosecutor, 127 of which were investigated by the 'Novo Team'. Of these, 96 cases involved the investigation of Afghans, of which it seems that only a few revealed sufficient evidence of personal involvement in international crimes to establish a prosecution. ${ }^{51}$

Limitations in exercising universal jurisdiction in the Netherlands were further confirmed on 20 November 2000, when the Court of Amsterdam took a decision in Bouterse, a case that considered the legal grounds for liability and prosecution in the Netherlands of crimes against humanity and violations of the Convention Against Torture. ${ }^{52}$

In light of these factors, unless substantial and deliberate steps are taken by the government to form a coherent policy, it is doubtful that prosecution for international crimes can be established in Dutch law.

\section{ATTEMPTING TO RESOLVE THE TENSIONS}

Having considered the tensions that arise in the exercise of these two principles of exclusion and universal jurisdiction, it is worth considering how they might be resolved. It is proposed that this involve essentially three areas: better co-ordination between the relevant government departments responsible for exercising asylum determination and exercising prosecutions; a firm guarantee of due process in the exercising of exclusion determinations; and finally, a principled, rights-regarding commitment to carry through with the principle of aut dedere aut judicare.

\subsection{Recognising the Interface}

As a starting point, it is important to be deliberate and pragmatic in pursuing these principles, recognising that there is an interface in the invocation of exclusion and the exercise of universal jurisdiction, each

\footnotetext{
50 It is understood by the author that at the time of writing, the staff of this unit has increased.

51 Question in Parliament about the NOVO team, 8 February 2001, to the Minister of Justice and confirmed by Beijer, Klip, Oomen and Van der Spek, op.cit. (note 49).

52 The case was in respect of the so-called 'December Murders', which took place in 1982 in Surinam. Prof. Mr G.A.M. Strijards, commenting on the case in 'Nederlands Dualisme en zijn strafmacht', Nederlands Juristenblad 2000/44, noted that lack of a basis for jurisdiction preventing prosecution arose as the Convention Against Torture only came into force in 1989 , seven years after the crimes took place.
} 
having their separate yet complementary functions. By extension, there is a need for greater co-ordination between the departmental authority responsible for asylum determination (and invoking the exclusion clause) and the authority responsible for pursuing prosecutions in application of the universal jurisdiction principle. ${ }^{53}$ Both must be clear about the implications of an exclusion determination, and these implications must be clearly communicated to the applicant concerned.

\subsection{Importance of Due Process Standards}

This analysis clearly shows that the central tension that arises between these two principles concerns the need to exercise an adequate standard of due process in making an exclusion determination. The legitimacy of a country's asylum determination regime is at grave risk when the pressure to prosecute outweighs fundamental human rights standards in determining whether or not an applicant ought to be subject to an exclusion determination in the first place. Furthermore, a universal jurisdiction claim exercised under such circumstances might have little chance of ending in a successful prosecution. Therefore, resolving the 'central tension' between these two principles must necessarily involve enhancing due process in the exercise of an exclusion determination. ${ }^{54}$ More specifically, the standards for guaranteeing due process in exclusion cases demand that such determinations be free of bias, that due consideration be given to the 'serious reasons' standard, that in appropriate cases proportionality be properly and consistently measured (weighing the crime committed against its political objective), and that the decision be based on a properly conducted interview.

\subsubsection{Avoiding 'Blind Blanket' Exclusions}

'Blind blanket' exclusions on the basis of pre-determined information (i.e., profiling of suspects, without adequate opportunity for individual hearings on an asylum claim) clearly reveals bias on the part of the authorities and should be avoided. ${ }^{55}$ Such an approach is not only in serious danger of compromising fundamental principles of refugee protection, but as illustrated above, is quite unlikely to stand up to court challenge. In any event, it presents a hasty, unconsidered response to pursuing justice against

\footnotetext{
$53 \quad$ Fitzpatrick, loc.cit. (note 17), p. 282.

54 See Gilbert, loc.cit. (note 16), as well as a comprehensive report produced by the Lawyers Committee for Human Rights, published in a Special Supplementary Issue of the International Journal of Refugee Law, Vol. 12, 2000.

55 Verdirame, loc.cit. (note 18), and the Lawyers Committee for Human Rights, supra note 56, at p. 338, both stress the need for an 'individualised procedure' for determining exclusion.
} 
alleged violators of international crimes, one likely to create a backlog of potential indictments that will prove virtually impossible to prosecute.

\subsubsection{Protecting the 'Serious Reasons' Standard}

There should be clear, enforceable guidelines on achieving the serious reasons standard required in international law and often reflected in legislation. ${ }^{56}$ A person must be judged on his or her personal involvement in alleged excludable offences. Such guidelines would need to include a credible admission from the applicant and more than mere membership of an organisation, in cases where there is considerable evidence that the organisation has committed excludable offences. Finally, as an additional measure for reaching the 'serious reasons' standard, it has been recommended by a legal advisory group commissioned by the Lawyers Committee for Human Rights that an equivalent of the evidentiary standard for issuing an indictment from the ICC would constitute "clear and convincing reasons' for invoking exclusion. ${ }^{57}$

\subsubsection{Considering Proportionality}

Secondly, the 'proportionality' regarding the political aspect of the accused's alleged offences ought to be duly balanced against a range of mitigating factors. The most obvious factor, in the case of the more common Article $1 \mathrm{~F}$ (b) exclusion determinations ${ }^{58}$ (most of which would probably not stand up to prosecution under the universal jurisdiction principle) is the political nature of the offence committed. Some suggest that Article 1F(b) should not be imposed 'where the severity of persecutory punishment would outweigh the criminal character of the offender'. ${ }^{59}$ However, in the case of any exclusion determination, all relevant mitigating factors must be taken into account, particularly in the case of applicants who may have been child soldiers. Such cases should receive special consideration. ${ }^{60}$

\footnotetext{
56 These recommendations partly draw upon a comprehensive report by the Lawyers Committee for Human Rights on the subject, loc.cit. (note 54).

57 'Safeguarding the Rights of Refugees under the Exclusion Clauses: Summary finding from the project and a Lawyers Committee for Human Rights Perspective', Vol. 12, Special Supplementary Issue, International Journal of Refugee Law, 2000, at p. 329.

58 Article $1 \mathrm{~F}(\mathrm{~b})$ of the $1951 \mathrm{UN}$ Refugee Convention, provides that an applicant may be excluded if 'he has committed a serious non-political crime outside the country of refuge prior to his admission to that country as a refugee' (emphasis added).

$59 \quad$ Fitzpatrick, loc.cit. (note 17), at p. 277.

60 See the 'Impact of Armed Conflict on Children: Report of the expert of the SecretaryGeneral, Graça Machel', submitted pursuant to General Assembly Resolution 48/157; The Convention on the Rights of the Child, adopted by the General Assembly of the United Nations on 20 november 1989, UNGA Resolution 44/25; and Refugee Children: Guidelines on Protection and Care, UNHCR, Geneva, 1994.
} 


\subsubsection{Properly Conducted Interview}

There must also be a properly conducted interview, as opposed to an interrogation, which often occurs in the pursuit of Article 1F exclusion enquiries. Such an interview ought to be orientated towards establishing the facts of a particular applicant's circumstances; namely, what they might have done that could qualify or exclude them from being recognised as a refugee. Conducting such an interview is by no means an easy task, requiring highlevel communication skills. ${ }^{61}$ It is only after such fact-finding has been undertaken that a departmental authority will be in any position to make a sound judgement on an applicant's claim.

Following such a fact-finding interview, if the determination official intends to invoke the exclusion clause, the applicant ought to be informed that exclusion is being considered, and the consequences should be explained to him or her. Such a determination ought to be reached only after an oral hearing (allowing the applicant to present his/her side of the story), which incorporates appropriate procedural safeguards, provides an opportunity for independent review and, most crucially, permits access to competent legal assistance.

It is only if these criteria have been met that an accused ought to be extradited to the jurisdiction of an international court or tried for an international crime under the universal jurisdiction principle.

\subsection{Consequences of Exclusion: Aut dedere aut judicare}

If properly implemented rights-regarding exclusion procedures are followed, the aut dedere aut judicare principle can be a potentially important tool for ensuring compliance with international human rights standards and curtailing the impunity of human rights violators. ${ }^{62}$

Aut dedere aut judicare entails an obligation to ensure a prosecution against someone who has committed serious human rights crimes. In practical terms, this means one of three things: deportation to one's country of origin to face prosecution; extradition to another jurisdiction (whether this be another national jurisdiction, an ad hoc tribunal or the soon-to-beestablished international criminal court) $;^{63}$ or prosecution within the host State in terms of the universal jurisdiction principle.

$61 \quad$ For a useful survey of some of the 'bottlenecks' encountered in communicating with groups from markedly different cultural backgrounds (in this case the Somali community in the Netherlands), see Nieuwhof, A. and Mohamoud, A., 'Communicatie, sleutel tot participatie' [Communication, the key to participation], Ministerie van Binnenlandse Zaken [Internal Affairs], The Hague, March 2000.

62 Although, it would be difficult, if not impossible, to attach any obligation to it, particularly by protection agencies such as the UNHCR. Fitzpatrick, loc.cit. (note 17), at p. 279, states very clearly that 'the UNHCR has no aut dedere aut judicare obligation under international law'.

63 States should also develop clear structures for rendering suspects to the ad hoc tribunals and the International Criminal Court. Some have already done so. 
In all cases of exclusion, extradition and deportation must be carried out in accordance with two main safeguards. Firstly, due consideration must be given to human rights protections provided for in certain universally binding international human rights instruments; ${ }^{64}$ the likelihood (or lack thereof) of a fair trial in the receiving country, for example, would be one such area of concern. ${ }^{65}$ Secondly, States party to the Convention Against Torture are prohibited from deporting a person to a country where they would face a substantial risk of torture.

The third option, prosecution in the host country in terms of the universal jurisdiction principle, can be a highly desirable outcome in the pursuance of international justice and contribute to the ending of impunity, again provided there is no danger of refoulement and that appropriate safeguards for a fair trial are in place. ${ }^{66}$ Prosecution of these offences should be prompt, avoiding a situation where accused persons languish in prison for years. Furthermore, as mentioned earlier, it must be clearly understood that not all excludable offences will be prosecutable in terms of international criminal law; indeed, few of them will.

Under current circumstances, it is highly doubtful whether the objective of Article $1 \mathrm{~F}(\mathrm{a})$ - concerning international crimes - can be satisfactorily fulfilled if no international or national (universal) jurisdiction can be established to pursue a prosecution. Furthermore, it remains unclear whether aut dedere aut judicare applies as a matter of obligation following an exclusion determination; even recognising the existence of universal jurisdiction as a juridical concept is not without its complications. ${ }^{67}$

$64 \quad$ Notably the 1948 Universal Declaration of Human Rights, UNGA Resolution 217 A(III) and the 1966 International Covenant on Civil and Political Rights, UNGA Resolution 2200 $\mathrm{A}(\mathrm{XXI})$, both of which are widely regarded as part of international customary law and thus universally binding.

65 Bruin and Wouter, loc.cit. (note 9), would no doubt agree, having considered the implications of deportation following an Article $1 \mathrm{~F}$ determination with extensive reference to the approach adopted by the Canadian High Court.

66 The military commissions proposed in the United States, by contrast, should be resisted. See Fitzpatrick, J., 'The Constitutional and International Invalidity of Military Commissions under the November 13, 2001 "Military Order", (unpublished paper), posted on the IMMPROF list-server on 28 November 2001 and a range of views by NGOs such as Amnesty International (www.amnesty.org), the American Bar Association (www.abanet.org/media/jan02/terrorism_milcomm.html), Human Rights Watch (www.hrw.org) and International Commission of Jurists (www.icj.org), to name but a few.

67 There are some who endorse principles of international criminal law as being part of international customary law. Gilbert, loc.cit. (note 16), at p. 12, quotes Cassese: 'customary international law imposes criminal liability for serious violations of common Article 3 (relating to the Geneva Conventions referring to various international crimes), as supplemented by other general principles and rules on the protection of victims of internal armed conflict, and for breaching certain fundamental principles and rules regarding means and methods of combat in civil strife'. Others resist the use of international customary law to 'fill up any jurisdictional gaps' in establishing a universal jurisdiction claim; see Wilt, H. van der, in: AFLA Quarterly, ibidem, at p. 22. 
Dealing with excluded applicants thus creates a difficult conundrum. On the one hand, there is the principle that such persons are entitled to a fair trial, which may prevent deportation or extradition to a country where the crimes were allegedly committed. ${ }^{68}$ On the other hand, failure of governments to establish jurisdiction, let alone build a sufficient case, prevents a 'local' prosecution from taking place.

Coupled with the lack of a mechanism for ensuring rights-regarding asylum determinations, and in cases where some governments (such as the Netherlands) are willing to exercise a broad standard in invoking Article $1 \mathrm{~F}$ against asylum applicants, both the non-refoulement principle and the aut dedere aut judicare principle are simultaneously in danger of being compromised.

\section{CONCLUSION}

As this article has attempted to illustrate, tensions between the principle of exclusion and the principle of universal jurisdiction (indeed, establishing jurisdiction to prosecute international crimes generally) result from the different objectives of international humanitarian law and human rights law. This has two main consequences: the first is an added tendency towards restrictive policies in asylum determination; the second poses a tricky paradox, as described above, when it comes to dealing with applicants after they have been excluded. Both require a major rethinking of the operation of Article $1 \mathrm{~F}$ as a sine qua non for ensuring rights-regarding determination procedures, and an effective exercise of jurisdiction over international crimes.

Resolving these tensions requires firstly ensuring better communication between the relevant authorities responsible for exercising exclusion and exercising prosecutions under the universal jurisdiction principle, with both authorities recognising from the outset, and communicating to the applicants concerned, that the outcomes of exclusion may in some cases lead to a criminal prosecution. Secondly, resolving these tensions requires that there be acceptable standards in asylum determination systems responsible for exercising exclusion and a firm commitment to carry out the explicit intentions of aut dedere aut judicare.

The operation of exclusion in the Netherlands is a good example of why some believe that a 'crisis' exists in the international asylum regime. However, rather than simply adapting the system to meet the political interests of governments keen to limit the number of asylum claims while also pursuing an increasingly aggressive strategy towards those accused of committing international crimes, it is suggested that the answer lies

\footnotetext{
68 Gilbert, loc.cit. (note 16), who recognises the principles of non-refoulement and freedom from torture as peremptory norms, at pp. 8, 24, 30 and 43, is unequivocal: 'The fear of persecution should prevent refoulement no matter what the crime - a very serious crime should be prosecuted in the state where the applicant seeks refugee status' (ibidem, p. 19).
} 
primarily in a principled commitment to human rights. Ensuring that due process guarantees are respected in exercising asylum status determination, coupled with a firm commitment to consider exercising criminal jurisdiction over those who it is determined are appropriately to be excluded from refugee protection, will both enhance the credibility of asylum regimes and result in more successful prosecutions.

Rather than operating against each other, the two principles of nonrefoulement and aut dedere aut judicare should be seen, and implemented, as complementary instruments, both to protect the victims of human rights violations and ensure that the impunity of the perpetrators of such violations is ended. 
